\title{
Sectoral risk assessment with particular emphasis on export enterprises in Poland*
}

\author{
Natalia Nehrebecka ${ }^{1}$
}

\begin{abstract}
The article presents a methodological framework for the analysis of sectoral risk and an evaluation of the financial condition on sectors level. In addition, the hypothesis was verified that the financial constraints of enterprises affect decisions making by prospective exporters and sales in foreign markets. The empirical analysis was based on the individual data from different sources (from the years 2005 to 2016), which are: balance sheet and profit and loss account (Statistical Office), financial and behavioural data. The evaluation consists of two parts. The first part presents the financial strength depending on the net value of enterprises. The financial strength defines the financial capacity of enterprise. The second part presents Probability of Default (PD) model. The statistical model is built on logistic regression model, and produces an estimate of the annual PD of the assessed company. Based on the results of the evaluation of the risk associated with the financial condition of enterprises, it was found that SMEs faced a higher risk. The lowest risk of bankruptcy was observed in the pharmaceutical industry and the highest risk of bankruptcy - in the mining sector. Exporters were characterised by better financial equipment.
\end{abstract}

Key words: sectoral risk, bankruptcy risk, scoring methods, export

JEL classification: C190, G210, L11, L25, G33, M13

\section{Introduction}

Macroeconomic conditions in which companies operate are an important aspect in the analysis of the factors affecting the financial condition of enterprises, the risk of bankruptcy, and transition of enterprises from the high-risk group to the group of enterprises whose financial condition is good, and vice versa.

\footnotetext{
* Received: 06-06-2018; accepted: 29-11-2018

1 Assistant Professor, Warsaw University - Faculty of Economic Sciences, Dhuga 44/50, 00-241 Warsaw, Poland. National Bank of Poland, Świętokrzyska 11/21, 00-919 Warszawa. Scientific affiliation: econometric methods and models, statistics and econometrics in business, risk modeling and corporate finance. Phone: +48225549111.Fax:228312846.E-mail:nnehrebecka@wne. uw.edu.pl. Website: http://www.wne.uw.edu.pl/index.php/pl/profile/view/144/.
} 
The IRB credit risk evaluation concept is based on the assumption that the risk to the credit portfolio may result from two sources:

- systemic risk, which is caused by unexpected macroeconomic and market changes. The risk is faced by all borrowers; however, the level of susceptibility of individual borrowers to this risk may be different;

- idiosyncratic risk, which is the outcome of various unique threats faced by individual borrowers.

In case of non-financial firms their default display positive correlations within and across industries. Their dependence structure might by driven by sectoral (systematic) risk factors. (Das et al. 2007; Saldías 2013).

Sectoral risk is taken into account in credit risk modelling. It includes latent sectoral risk factors influencing the correlation of defaults among firms. Sectoral risk reflects important risk component in credit portfolios that arises when there is a concentration of borrowers in a sector. Sectoral risk represents the instability of the banking system when capital requirements for exposures to a given sector are inappropriate comparing to those that take into account sectoral risk.

ESRB (2015) shows that a build-up of sectoral vulnerabilities can become a source of systemic risk. For example, if the aim is to slow down credit growth in the real estate sector a reasonable solution would be to consider first instruments that specifically target mortgage lending and not broad credit instruments such as the counter-cyclical capital buffer.

The article presents a methodological framework for the analysis of sectoral risk and an evaluation of the financial condition on sectors level. In addition, the hypothesis was verified that the financial constraints of enterprises affect decisions making by prospective exporters (Chaney, 2016) and sales in foreign markets (Manova, 2013). The theory regarding the relationship between exports and sources of investment financing is still underdeveloped, and models that take this problem into consideration have only been in existence for several years. The results of studies conducted so far are not conclusive. Individual data from yearly financial reports for the years 2005-2016 is used in the analysis. This research has an original concept and high added value as it was performed using representative micro data for over 50,000 non-financial companies per year.

The risk sector results from the current or forecast situation in the sector in which the enterprises operate (Gregoriou et al. 2010). In the present article, sector risk is defined as uncertainty concerning changes in the economic-financial situation of sectors. The sectoral analysis is a risk barometer and determines the indicators of insolvency for all enterprises conducting operations in specific sectors. Measurement of sector risk indirectly affects the significant problem of mutual influence of the economic 
situation for the country's economic development. These influences are reflected, for example, through profitability, investment opportunities, shaping public sentiment.

Based on the present literature on this subject manner, it can be concluded that the approach used in the present article concerning sectoral risk, which is based on individual data, has not been applied so far. The analysis was performed using logistical regression on categorised variables transformed using the WoE (Weight of Evidence) method. Scoring methods which enable division of enterprises according to their level of risk bankruptcy were used. When other conditions imposed by regulatory authorities are met, the models that were designed could be used among others in the process of calculation of capital requirements. Jankowitsch et al. (2007) demonstrated that such application of the model can bring real benefits for banks.

The remainder of this paper is organized as follows. Section 2 presents a review of empirical literature on sectoral risk analysis. Section 3 presents the methodology, and Section 4 the data. Section 5 presents and discusses the empirical results, while Section 6 concludes the paper.

\section{Literature review}

Literature review consists of two parts. The first part concerns the presentation of existing research related to sectoral risk. Based on the literature review, the above phenomenon can be considered in two ways. The first approach related to the definition of sectoral risk as uncertainty concerning changes in the economicfinancial situation of sectors. The second approach related to firms default display positive correlations within and across industries. Their dependence structure might by driven by sectoral (systematic) risk factors (Das et al. 2007; Saldías 2013).

The second part of the literature review related to the influence financial constraints of enterprises affect decisions making by prospective exporters (Chaney, 2013), also impact of financial constraints on sales in foreign markets (Manova, 2013). Based on the literature review two factors can be found that:

- exporters have a better financial situation than their non-exporting competitors;

- there are significant differences between countries in the issues of export activity of enterprises.

\subsection{Determinants of insolvency for all enterprises conducting operations in specific sectors}

Based on the analysis of the literature concerning the sectoral risk, Nguyen (2007) remarked that quite frequently sectoral risk is defined as the average risk 
of enterprises conducting operations in the sector. The basic problems with measurement of the risk are identification and definition of an appropriate risk variable. In the case of sectoral risk, various concepts of measurements and various methods of its assessment are used. Falk and Heintz (1975) studied sectoral risk based on sectoral characteristics that are reflected in the financial indicators. A critique of this approach was presented by Blocher and Chen (1978) who also presented proposals concerning the solution of the problem with the selection of financial indicators. Another group of studies covers profitability and sectoral risk depending on the market structure (Demsetz 1973; Esposito 1985). Nguyen (2007), following Merton's (1974) model of insolvency, performed an assessment of sectoral risk using a measure based on a distribution of cash flow to all companies at a sector level.

A different approach to sectoral analyses is presented in analyses focusing on sectoral concentration. Studies on sectoral concentration have been analysed by Düllmann and Masschelein (2006). The authors studied the extent to which sectoral concentration contributed to an increase in the economic capital and checked the effectiveness of various methods - other than Monte Carlo simulations - methods of measurement of the risk of sectoral concentration. It was confirmed that economic capital increased with an increase in sectoral concentration. Holub et al. (2015) studied the risk resulting from the sectoral concentration of credit portfolios and found that, due to its level and its impact on the credit risk, banks should establish additional capital requirements. The level of sectoral concentration and its trends were determined using the HHI indicator. In the opinion of Accornero et al. (2017), a high concentration of a bank's involvement in sectors of the economy that are more sensitive to the business cycle can significantly contribute to an increase in the credit risk of the bank. This is particularly important in periods of slower economic growth or recession because excessive credit concentration in sectors that are sensitive to the changes in the business cycle in such periods can result in financial losses that pose a threat to the bank's solvency. It was determined that credits granted concentrated in three sectors: the industrial sector $(20 \%$ of the total credit exposure), the commerce sector (14\% of the total credit exposure), and the construction sector ( $13 \%$ of the total credit exposure). Those sectors are the riskiest and are characterised by the highest ratio of unexpected losses in relation to the value of the exposure. The average probability of bankruptcy in each of the sectors is higher.

Heifitfield et al. (2005) presented a study on the impact of systematic and idiosyncratic risk on the distribution of portfolio loss. Saldias (2013) uses panel data to analyse systematic and idiosyncratic determinants of the risk of insolvency in the corporate sector of the Eurozone. The author studies the way that the risk of bankruptcy of entities is transferred between/within the financial sector and the corporate sector. This approach takes into account observable and latent factors 
and presents s different level of sectoral dependence between entities. Iosifidi and Kokas (2015) showed that banks characterised by a higher credit risk grant loans to companies that are riskier and whose financial condition is worse (selection mechanisms). The results of the study point at the need to monitor banks with elevated credit risk.

\subsection{Determinants of firm export activity}

In addition, the hypothesis was verified that the financial constraints of enterprises affect decisions making by prospective exporters (Chaney, 2016) and sales in foreign markets (Manova, 2013). Manova (2013) claims that enterprises need to borrow to cover part of the variable costs related to production for export. This results in a decrease in export intensity in relation to a situation where the company would only aim to maximize profits. However according to Chaney (2016), that companies cover production costs with the use of profits obtained as a result of sales on the domestic market, which suggests that the company's productivity is more important in the case of export intensity. The results of studies conducted so far are not conclusive. Bellone et. al. (2010), when analysing new French exporters, did not obtain the impact of investment financing on export intensity, while they received a strong dependency indicating the impact of financial constraints on entering foreign markets. Similar results for Chinese companies were obtained by Egger and Kesina (2014). However, Minetti and Zhu (2010) research on Italian companies' supports the Manova hypothesis. The authors prove the negative impact of credit restrictions on both the export decision and the size of export sales. The same conclusions are drawn by Kiendrebeogo and Minea (2013), which study concerns Egyptian companies. Therefore, both for developed and developing countries, the results of the research are not conclusive that makes the study on Polish data a very interesting research topic.

\section{Methodology}

In this section the first part of the methodology is presented sector risk associated with their activities. Based on the existing literature, the approach used in the article on sectoral risk was not applied, as it is based on individual data. Assessment of financial standing in a given sector of operations is composed of two parts. The first part presents the financial strength depending on the net value of companies. Financial strength represents companies' financial capacity. The second part of the assessment is related to the risk of bankruptcy.

In the second part, the methodology of estimation of dynamic panel models is discussed, which was used in the empirical study of verification that the financial constraints of enterprises affect decisions making by prospective exporters (Chaney, 
2013), also impact of financial constraints on sales in foreign markets (Manova, 2013).

\subsection{Sectoral risk assessment}

The evaluation consists of two parts: the financial capacity and the risk of bankruptcy. The first part presents the financial capacity depending on the net value of enterprises. The financial capacity defines the financial capacity of an enterprise. The defined classes 1-4 are considered to be low-risk groups, with the first group being the group with the lowest risk. The safety of class 5 is average. Classes 6-13 are considered to have an above-average risk, whereby the 13th group is associated with the highest risk. Class (-1) groups enterprises with negative equity. The second part of the evaluation concerns the risk of bankruptcy. In this paper it was used the "narrow" definition (failure) is based on the assessed entity filing a formal application for bankruptcy proceedings (see Nehrebecka, Dzik, 2016).

Probability of default $P D$ model consists of the next part:

Quantitative - financial factors $(F)$,

Qualitative - behavioural factors (B) (localization of the entity, industry, size of employment, legal form, year of establishing, description of the owner, payment morality)

\section{Sector riskiness $(S)$.}

The model was combined by formula:

$$
y=F^{\alpha} B^{\beta} S^{\gamma}
$$

Previous model consists only with financial factors (see Nehrebecka, Dzik, 2016; Nehrebecka 2016).

Every firms who bankrupt within outcome period stayed in the sample. The non-bankrupt cases were then randomly reduced to satisfy the condition that bankrupts accounts for about $20 \%$ of the sample. Then the dataset was randomly split into development and validation sample containing $70 \%$ and $30 \%$ of the data, respectively. Due to the way the data sample was constructed it was tested whether selected non-bankrupts are representative for the whole population. The distributions of the variables before and after categorization were compared. For continuous variables two nonparametric tests, Wilcoxon-Mann-Whitney test and Kolmogorov-Smirnov test, were applied to check whether samples are drawn from the same population. For categorical variables a Pearson test and Population Stability Index was used. 
The single factor analysis was performed to identify variables that stand-alone are predictive for bankrupt/non-bankrupt. It was verified whether variables have explanatory power and an intuitive relation with the bankruptcy rate. Two measures were used to assess the predictive power of the variables: Gini coefficient ${ }^{2}$, Information Value ${ }^{3}$.

The continuous variables were categorized. Applied categorization leads to eight final categories maximizing Information Value. Separate category for missing values was created. In high dimensional data sets, identifying irrelevant factors is difficult. Variables clustering was applied to find groups of variables that are as correlated as possible among themselves and as uncorrelated as possible with variables in other clusters. A variable selected from each cluster have a high correlation with its own cluster and a low correlation with the other clusters.

Variables were transformed into WoE's (Weights of Evidence) - this has the advantage, that no special treatment of missing and/or outliers is necessary. Outliers are not cut off, and missing values simply form a category of their own. The Information Value and Gini coefficient for a variable were calculated for training and holdout sample. The stability of variables in time was tested. Relation of WoE for categorized variables was investigated. Logit model was estimated on variables transformed into WoE which were then standarized. The stepwise method was used.

\subsection{Modelling of export decision-making determinants}

A dynamic econometric model has been estimated, describing how the financial constraints of enterprises affect decisions making by prospective exporters (Chaney, 2016) and sales in foreign markets (Manova, 2013). A special class of the econometric models used are dynamic models estimated using panel data. These are characterized by a significant impact on the dependent variable of the time factor, which is taken into account by applying lagged values of selected variables as regressors. This method allows us to account for the dynamic character of the problem studied. Despite such a broad range of dynamic applications of panel models in relation to enterprise finance, estimation of them still poses many difficulties, which is caused by the specific character of the data. Firstly, what can be observed is that companies are highly heterogeneous, which is reflected in the individual effect, taken into account in the estimated model (time independent). What is, however, more significant in the research of enterprise finance is that

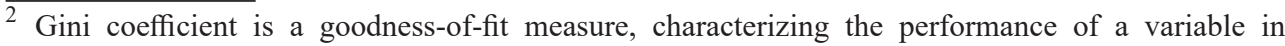
predicting a binary dependent variable. Gini coefficient is between zero and $100 \%$.

${ }^{3}$ Measure based on weights of evidence. The Information Value can be interpreted as the statistical distance between the bankrupts and non-bankrupts' distributions. The larger the Information Value the better the discrimination of the variable.
} 
some explanatory variables are commonly endogenous. Additionally, in relation to the correlation between the individual effect of the entities and the lagged dependent variable included in the modelling, the standard methods of estimation used for static models (OLS estimator for panel data, Fixed Effect estimator, and Random Effect estimator) will not be aligned. This excludes their use in dynamic modelling.

In the constantly developing empirical research on the finances of enterprises, the authors usually use one estimator for the dynamic model. However, selecting the relevant method among the broad range of estimators dedicated to assessing dynamic models using panel data would allow for more precise estimations. In order to select an appropriate econometric tool, the properties of estimators in dynamic models, estimated on panel data, were tested. An achievement is also the indication that an appropriate method for estimating dynamic models on panel data, taking into account the length of the panel and the occurrence of correlation between the individual effect and the initial values of the explained variable, is a system estimator of the GMM Blundell-Bond estimator (see Arellano, Bover 1995; Blundell, Bond 1998). The models were diagnosed in terms of the correctness of the selection of instruments using the Sargan test verifying the non-autocorrelation of instruments with the random component of the model. Additionally, on the basis of the Arellano-Bond test, the assumption was made about the lack of second-order autocorrelation of the random component.

\section{Empirical data and analysis}

The purpose of this chapter is to describe the database and variables used in the sector risk analyses and those used in the study to verify the related hypothesis, that financial constrains matter for export participation and sales in foreign markets.

\subsection{A case of polish sectoral risk assessment}

The empirical analysis was based on the individual data from different sources (from the years 2005 to 2015), which are: balance sheet and profit and loss account (F-02 statement), financial and behavioural data (BISNODE POLAND). The analysis was made for active entities (according to the definition of the Statistical Office). At a given time, each of the studied companies could have one of the following four statuses of legal and economic activity: active entity conducting activities, an active entity in construction, an active entity in liquidation, and active entity in bankruptcy. Consequently, failure forecasting applies to entities that, as of 31 December, are in bankruptcy but continue their activities and had revenue from the activities in the period covered by the report. 
Natalia Nehrebecka $\bullet$ Sectoral risk assessment with particular emphasis on export...

Figure 1: The share of firms by brand activity (in 2015)

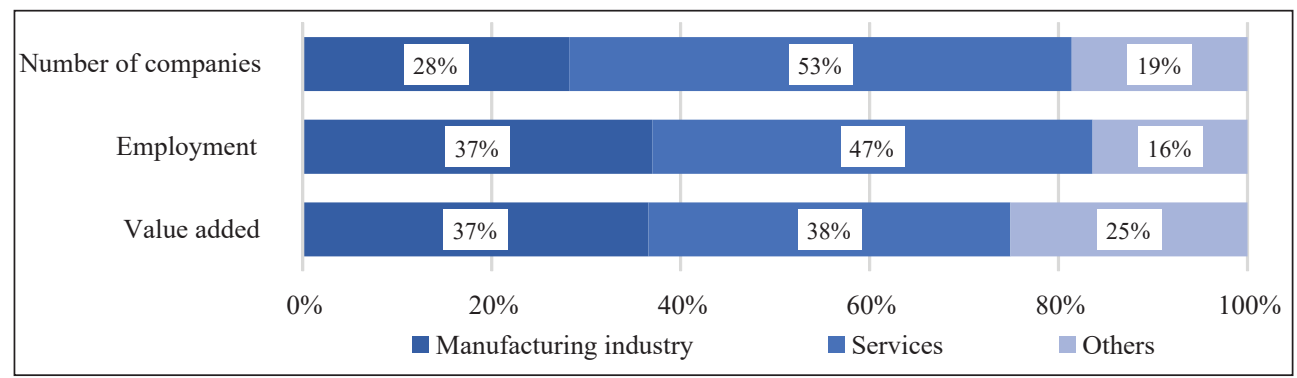

Source: Authors' calculations

In 2015 , the manufacturing industry enterprises generated $36 \%$ of the overall added value in the non-financial sector (Figure 1). They accounted for $28 \%$ of companies and employed $37 \%$ of employees. In 2015 service providers generated PLN 251 billion of added value (38\% of the sector of non-financial enterprises). They accounted for $53 \%$ of companies and employed over 2,4 million people (46\%). Large enterprises ( $4 \%$ of the total number of enterprises) generated $52 \%$ of the overall added value and employed $38 \%$ of staff. The percentage of large enterprises in the manufacturing industry was higher $(6 \%$ in 2015$)$ than in services $(3 \%)$.

To analyze the links between GDP and the number of business bankruptcies in Poland in the period of 2005-2016, an overview of the dynamics of their changes during this period was made (Figure 2). There is a negative relation between the GDP growth rate and the number of bankruptcies declared by courts. It should be noted that the number of actual bankruptcies is frequently much higher as some of the petitions are returned due to formal deficiencies or dismissed as a result of a shortage of assets. In particular, small companies end their business activity without undergoing the bankruptcy procedures.

Figure 2: The number of business bankruptcies vs. GDP

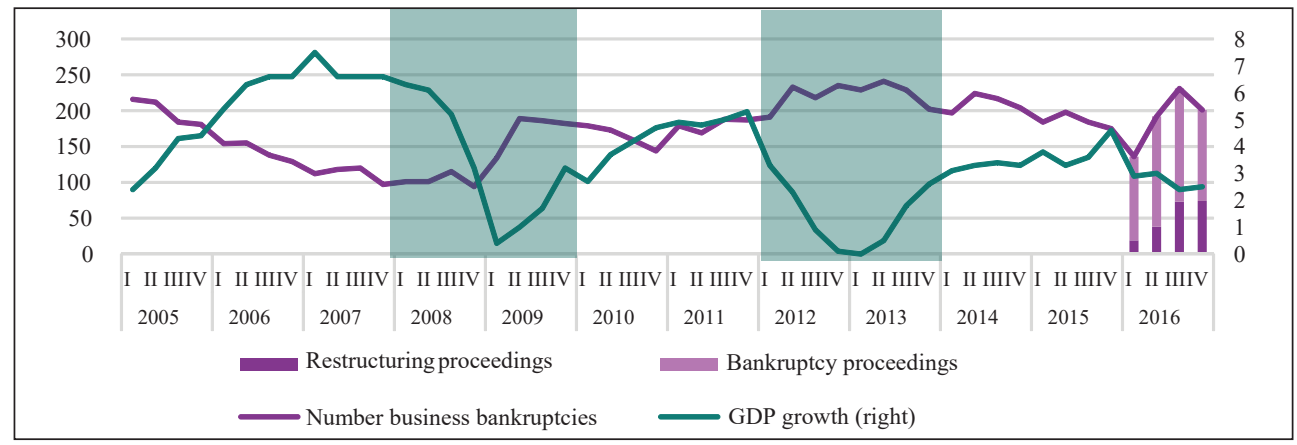

Source: Authors' calculations 
The evaluation of the sectoral risk consists of two parts: the financial capacity and the risk of bankruptcy. The first part presents the financial capacity depending on the net value of enterprises. The analysis of the aforesaid data led to a conclusion that in 2005-2015, in terms of financial capacity, all non-financial enterprises fell under the risk classes 4 to 8 (the median of the financial strength was in class 5 (financial capacity from EUR 750K to EUR 1,750K), while the first quartile of financial strength was in class 8 (financial capacity from EUR 165K to EUR 300K)). In 2015, 16\% of enterprises were below class 8 . The trend was set by the SME sector, dominant in terms of the number of enterprises. The situation of large entities was different. They usually (in more than 90\%) fell under the first four (safer) risk classes. The SME sector featured a higher percentage of enterprises with negative goodwill. Among large enterprises, the percentage of companies with negative goodwill was 2-3 percentage points lower on average than among SME, and it has remained at the level of 5\% since 2008. Exporters were characterised by better financial equipment (Figure 3).

Figure 3: Financial capacity in 2015 (\% firms)

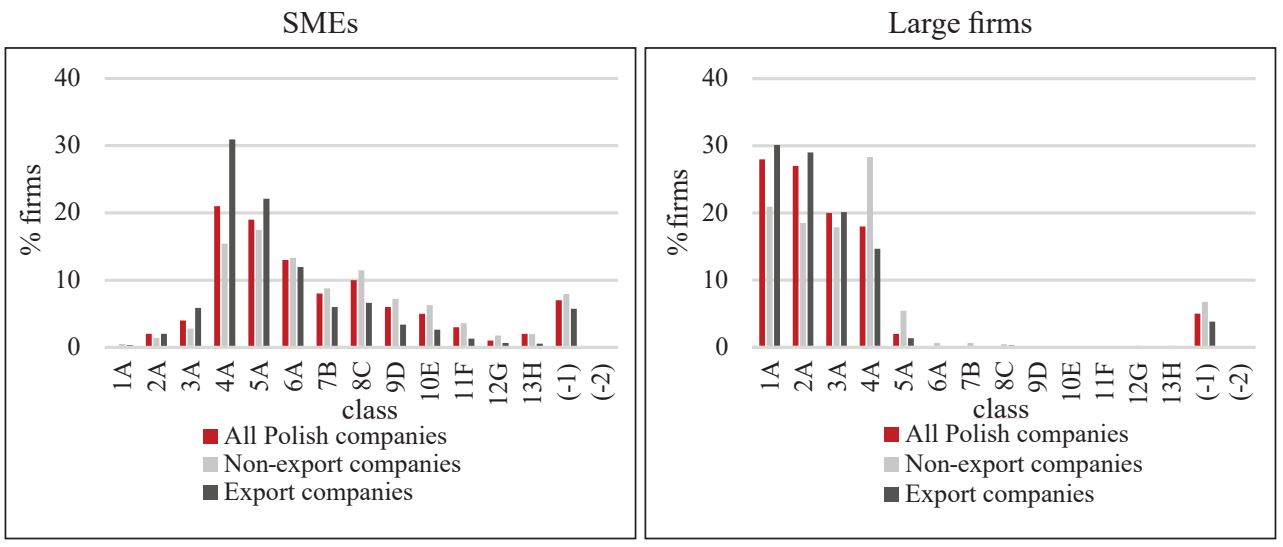

Source: Authors' calculations

In 2015 the sector of small and medium-sized non-financial enterprises was dominated by entities classified in groups with above-average risk (classes 6-13). The highest percentage of such enterprises $(50 \%)$ was present in the retail sector, companies providing business services, the construction sector, and the transportation and storage sector. The lowest percentage of such enterprises was present in the pharmaceutical sector (17\%), and the real estate activities sector. The enterprises that constituted the highest percentage in the group of enterprises with the highest financial capacity (classes 1-4) was small and medium-sized enterprises in the real estate activities sector (above 66\%), the energy, water and waste sector $(54 \%)$, and the pharmaceutical sector (52\%). The enterprises that constituted the lowest percentage in the lowest-risk group $(10 \%)$ was enterprises in the retail sector. 
The largest group of enterprises with negative net goodwill was service companies. Those were enterprises active in the accommodation and food service activities sector $(15 \%)$, the information and communication sector $(13 \%)$, the retail sector $(11 \%)$, and the business services sector $(11 \%)$. The enterprises in the manufacturing industry included those in the pharmaceutical sector (9\%), the textiles, clothing and footwear sector $(8 \%)$, and the metallurgy sector $(7 \%)$. The smallest percentage of enterprises with negative net goodwill was present in the energy, water and waste sector $(2 \%)$ and the real estate activities sector $(3 \%)$.

The situation in the last year of the analysis was different in the large enterprise sector. More than $80 \%$ of large non-financial enterprises were classified in the low-risk group that is characterised by the highest financial strength. Among the enterprises in the manufacturing industry, this share did not drop below 93\%. All enterprises in the first four risk classes were present in the case of the textiles, clothing and footwear sector, the chemical industry, the pharmaceutical sector, as well as the accommodation and food service activities sector and the real estate activities sector. The smallest percentage of enterprises in the lowest-risk groups was present among service enterprises providing business services (less than $84 \%$ ). An analysis of the above-average risk group indicated that the largest percentage in the risk classes 6-13 in 2015 was present among enterprises in the business services sector (8\%). The largest percentage of entities with negative goodwill was observed among service enterprises in the information and communication sector (12\%) and in the mining and quarrying sector (11\%). A share of entities with negative net goodwill that was higher than 5\% was also observed in the transportation and storage sector, the retail sector, the metallurgy and metalworking sector, and in the construction sector.

The second part of the evaluation concerns the risk of bankruptcy. The first included companies observed in 2014. In this model the Probability of Default (PD) was predicted for a one year horizon (Table 1).

Table 1: Bankruptcy rate (\% of the total number of enterprises) during one year (2015)

\begin{tabular}{|l|c|c|c|c|c|c|c|c|c|c|c|}
\hline & Class 1 & Class 2 & Class 3 & Class 4 & Class 5 & Class 6 & Class 7 & Class 8 & Class 9 & Class 10 & Total \\
\hline Total & 0 & 0 & 0,01 & 0,01 & 0,02 & 0,18 & 0,76 & 1 & 1,5 & 6,19 & 0,06 \\
\hline
\end{tabular}

Source: Authors' calculations

The defined classes 1-4 are considered to be low-risk groups, with the first group being the group with the lowest risk. The safety of class 5 is average. Classes 6-10 are considered to have an above-average risk, whereby the 10th group is associated with the highest risk. 
Natalia Nehrebecka $\bullet$ Sectoral risk assessment with particular emphasis on export... Zb. rad. Ekon. fak. Rij. • $2018 \cdot$ vol. $36 \cdot$ no. $2 \cdot 677-700$

Table 2: Evaluation of the risk of bankruptcy ( $\%$ of the total number of enterprises) in $2015^{4}$

\begin{tabular}{|l|r|r|r|r|r|r|r|r|r|r|r|}
\hline \multirow{2}{*}{ Total } & Class 1 & Class 2 & Class 3 & Class 4 & Class 5 & Class 6 & Class 7 & Class 8 & Class 9 & Class 10 & Total \\
\cline { 2 - 14 } & 7,26 & 14,29 & 28,87 & 25,32 & 14,22 & 7,57 & 0,89 & 0,88 & 0,26 & 0,44 & 100 \\
\hline B & 6,91 & 10,55 & 24,73 & 24,73 & 17,82 & 11,27 & 0,73 & 1,82 & 0 & 1,45 & 100 \\
\hline CA & 12,52 & 16,94 & 26,39 & 25,78 & 12,87 & 4,64 & 0,13 & 0,39 & 0 & 0,35 & 100 \\
\hline CB & 6,23 & 16,77 & 28,21 & 20,33 & 14,1 & 10,93 & 1,27 & 1,02 & 0,64 & 0,51 & 100 \\
\hline CC & 7,44 & 9,15 & 28,5 & 26,71 & 16,37 & 8,93 & 0,67 & 1,41 & 0,37 & 0,45 & 100 \\
\hline CE & 8,99 & 9,89 & 30,79 & 24,04 & 18,2 & 5,84 & 1,12 & 0,9 & 0 & 0,22 & 100 \\
\hline CF & 14,89 & 18,09 & 18,09 & 25,53 & 17,02 & 4,26 & 1,06 & 1,06 & 0 & 0 & 100 \\
\hline CG & 8,62 & 10,41 & 27,49 & 23,69 & 17,85 & 9,69 & 0,92 & 0,82 & 0,21 & 0,31 & 100 \\
\hline CH & 7,37 & 11,85 & 28,15 & 24,13 & 15,96 & 9,7 & 0,89 & 0,76 & 0,38 & 0,8 & 100 \\
\hline CI,CJ, & 8,38 & 11,39 & 29,06 & 22,68 & 17,72 & 7,38 & 1 & 1,38 & 0,19 & 0,81 & 100 \\
CK,CL & 9,45 & 16,38 & 29,68 & 27,52 & 12,07 & 3,73 & 0,23 & 0,76 & 0 & 0,17 & 100 \\
\hline DE & 5,16 & 10,77 & 23,04 & 25,3 & 19,45 & 12,34 & 1,38 & 1,45 & 0,51 & 0,6 & 100 \\
\hline F & 2,98 & 5,73 & 23,23 & 31,32 & 18,92 & 12,87 & 2,2 & 1,41 & 0,78 & 0,55 & 100 \\
\hline G45 & 6,12 & 9,66 & 29,9 & 26,37 & 16,44 & 8,23 & 1,15 & 1,26 & 0,4 & 0,47 & 100 \\
\hline G46 & 6,71 & 15,71 & 36,61 & 24,08 & 9,71 & 5,28 & 0,96 & 0,46 & 0,17 & 0,3 & 100 \\
\hline G47 & 9,02 & 11,24 & 32 & 29,82 & 10,34 & 6,42 & 0,66 & 0,43 & 0,04 & 0,04 & 100 \\
\hline H & 4,6 & 14,96 & 26,34 & 35,29 & 10,23 & 7,29 & 0,38 & 0,64 & 0 & 0,26 & 100 \\
\hline I & 8,44 & 22,55 & 27,13 & 20 & 12,15 & 7,42 & 0,87 & 0,58 & 0,15 & 0,73 & 100 \\
\hline J & 4,16 & 21,8 & 29,16 & 28,68 & 12,42 & 2,77 & 0,11 & 0,59 & 0 & 0,32 & 100 \\
\hline L & 8,06 & 21,36 & 28,89 & 22,83 & 10,46 & 6,49 & 0,67 & 0,58 & 0,2 & 0,46 & 100 \\
\hline Mc,N & & & & & & & & & \\
\hline
\end{tabular}

Source: Authors' calculations

Based on the results, it was found that the small and medium-sized enterprises faced a higher risk of bankruptcy than large enterprises, which was due to the fact that large enterprises have a higher rate of self-financing. About $76 \%$ of enterprises were included in classes 1-4, which are characterised by low risk (Table 2); those enterprises employed $76 \%$ of all employees (Table A1).

\footnotetext{
4 "B" - Mining and quarrying; "CA" - Agri food industries; "CB" - Textiles, clothing and footwear; "CC" - Wood, paper products and printing; "CE" - Chemicals industry; "CF" - Pharmaceuticals industry; "CG" - Manufacture of rubber and plastics; "CH" - Metallurgy and metalworking; "CI CJ_CK_CL" - Metal manufactures; "DE" - Energy, water and waste; "F" - Construction; "G45" - Motor vehicles trade; "G46" - Wholesale trade; "G47" - Retail trade; "H" - Transportation and storage; "I" - Accommodation and food service activities; "J" - Information and communication; "L" -Real estate activities; "Mc,N" - Professional, scientific, technical, administration and support service activities.
} 
Figure 4: Evaluation of the risk in 2015 (\% firms)

in the first two classes in which the PD does not in the last three classes in which the PD is equal to exceed $0.01 \%$

( $\%$ of the total number of enterprises)

( $\%$ of the total number of enterprises)
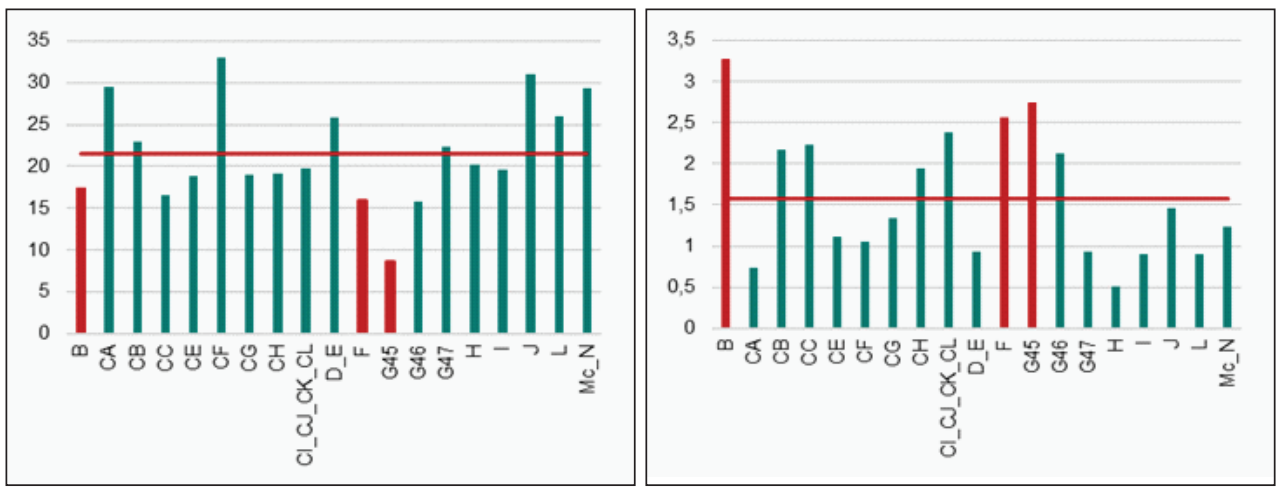

Source: Authors' calculations

Figures 4 and Figure 1A show a ranking of the sections of activities, which was determined based on the percentage of enterprises included in the categories where the probability of bankruptcy did not exceed $0.1 \%$ and those where it was equal to or higher than $1 \%$.

\subsection{Do financial constraints affect decisions making by prospective polish exporters?}

The empirical analysis of export decision and export intensity was conducted based on unit panel data, unbalanced, and originating from balance sheets and profit and loss accounts of Polish enterprises, presented in the Statistical Office reports. As far as financial leases are concerned, data annual statements of the period 2005-2016 (about 50,000 enterprises each year). We focused on non-financial enterprises, which, according to the Statistical Office results in exclusion from the study firms operating (according to the Polish Classification of Activities, 2007) in section $A$ (Agriculture, forestry, hunting and fishing), $K$ (Financial and insurance activities) and $O$ (Public administration and defence, compulsory social security). In addition. section $T$ (Activities of households, households producing goods and providing services for their own needs) and Section $U$ (extraterritorial organizations and bodies) were removed.

In 2015, the value of Polish exports amounted to EUR 184T. Polish goods went mainly to European markets (in 2014-2015, on average $88 \%$ of turnover) and to Asia and South America. The main trading partners of Poland consistently since 2015 were Germany, the United Kingdom, the Czech Republic, France and Italy. Over half of Polish exports included products of the electromechanical industry 
(in the years $2015-2016$ on average $41 \%$ ) and products of the chemical industry $(14 \%)$. The third place was occupied by agri-food products with ready-made food products, non-alcoholic beverages, alcohols, vinegar and tobacco at the forefront. Among the exported goods, the parts and accessories of cars, passenger cars and furniture and their parts dominated.

A dynamic econometric model has been estimated, describing how financial constraints of enterprises affect decisions making by prospective exporters and sales in foreign markets (Table 4). At the beginning of the estimation process of both models, the lagged period for the instruments in the equation on increments was selected. On the basis of the Sargan test, carried out for estimation that does not use the corrected estimator of variance, it was found that the best models have properties for which the first lagged of these variables were adopted as the endogenous variables. Sargan's test statistic was the highest for these models and was 67,21 and 93,63, respectively in the case of Model 1 and 2 (see Table 4), which implies no grounds for rejecting the null hypothesis about the correctness of instruments not used in the estimation process in the sense of their not correlating with the random components of the model. Additionally, based on the results of the Arellano-Bond test, there is no reason to reject the null hypothesis about the lack of second-order autocorrelation of the random component in the equation on increments. All estimations were performed based on a robust two-step procedure for estimating the systemic estimator of the generalized moment method.

Table 4: Do financial constraints affect decisions making by prospective exporters?

\begin{tabular}{|c|c|c|c|c|}
\hline Variables & \multicolumn{2}{|c|}{ Export decision } & \multicolumn{2}{|c|}{ Export intensity } \\
\hline Export decision $_{t-1}=\left\{\begin{array}{l}1 \text { if Export sales }>0 \\
0 \text { otherwise }\end{array}\right.$ & 0.699 & $(0.048)^{* * *}$ & & \\
\hline Export intensity $_{\mathrm{t}-1}=$ Export sales/Sales & & & 0.639 & $(0,044) * * *$ \\
\hline $\begin{array}{l}P D \text { (Probability of default, indicator built } \\
\text { on the basis PD model) }\end{array}$ & -0.177 & $(0.056)^{* * *}$ & $-0,184$ & $(0.073)^{* *}$ \\
\hline Company size $=\ln ($ Number of Employess $)$ & 0.048 & $(0.006) * * *$ & 0,040 & $(0.008)^{* * *}$ \\
\hline Productivity $=\ln (($ Value Added $) 7$ Employee $)$ & 0.039 & $(0.006)^{* * *}$ & 0.028 & $(0.008)^{* * *}$ \\
\hline Wage per employee $=\ln ($ Wage/Empoyee $)$ & -0.019 & $(0.014)$ & -0.023 & $(0.008)^{* * *}$ \\
\hline Test & \multicolumn{4}{|c|}{ Test statistic [p-value] } \\
\hline Time Dummies & 156.01 & {$[0.0000]$} & 99.01 & {$[0.0000]$} \\
\hline Sargan Test & 67.21 & {$[0.6054]$} & 93,63 & [0.2214] \\
\hline Arellano-Bond Test m1(p) & -4.58 & {$[0.0000]$} & -4.08 & [0.0000] \\
\hline Arellano-Bond Test m2(p) & 0.79 & {$[0.4245]$} & 0.23 & [0.8138] \\
\hline
\end{tabular}

Note: $* * * * *, *$ donate the significance level of $1 \%, 5 \%, 10 \%$ respectively. Robust standard errors are reported in the parenthesis. $\mathrm{p}$ - value is reported in the square brackets.

Source: Authors' calculations 
Using a large panel data of Polish firms, there was evidence that financial constrains $(P D)$ matter for export participation and sales in foreign markets $(-0.177$ and -0.184 respectively). This result corroborates the idea that the relevance of financial constraints was due to the presence of sunk entry costs. Enterprises need to borrow to cover part of the variable costs related to production for export. The important variable explained in the study of export activity in the scale of enterprises is productivity ( 0.039 and 0.028 respectively). Based on the theory, this is the key impact of this variable, mainly on entering the foreign market. Being an exporter has been recognized as a signal of high company productivity, which increases the lenders' trust. Ultimately, sales abroad lead to a reduction in susceptibility to demand and macroeconomic shocks as well as restrictive monetary policy. Using econometric models, the dependency on the size of enterprises was also identified (0.048 and 0.040 respectively). The size of the company turned out to have a positive impact on the tendency to be an exporter as well as on the intensity of exports. Large companies can gain a lot by producing on the foreign market. Wages per employee $(-0.019$ and -0.023 respectively) are negatively correlated with export performance, probably as they hamper competitiveness for a given level of labour productivity.

\section{Results and discussion}

For Poland non-financial corporations, Credit Assessment System (see: Nehrebecka, 2016) can estimate the risk of bankruptcy during the coming year. Based on the results of the evaluation of the risk associated with the financial condition of enterprises, it was found that small and medium-sized enterprises faced a higher risk (the evaluation consisted of two parts: evaluation of the financial strength and prediction of bankruptcy). Exporters were characterised by better financial equipment. The lowest risk of bankruptcy was identified in the case of the pharmaceutical sector (especially large enterprises) which, as has been mentioned, did not finance its activities with debt to such a high extent as other sectors. Of note is the fact that the pharmaceutical sector is one of the fastest growing manufacturing sectors both in Poland and abroad. The sector with the highest risk, where the PD was equal to or higher than $1 \%$, was the mining section. It was followed by the motor vehicles trade sector and the construction sector. The liquidity risk in the construction industry is still present and concerns mostly smaller entities, which are dependent on timely payments by general contractors or owners. This sector still generates many overdue liabilities, which also affects the situation of companies from other sectors of the economy that cooperate with construction companies.

A dynamic econometric model has been estimated, verifyingng the hypothesis that the financial constraints $(P D)$ of enterprises affect decisions making by prospective exporters (Chaney, 2016) and sales in foreign markets (Manova, 2013). Financial problems of companies cause that some of them refrain from the beginning of 
foreign expansion, despite the fact that in the conditions of perfect financial markets it could achieve export profits. Enterprises cover part of variable costs with the use of external financing sources, and limitations in their acquisition lead to a decrease in export intensity as well as profits from operations. It would be worth considering the ad hoc assistance for companies that export or plan to start exporting, but encounter problems with financing fixed costs or variable costs related to operating abroad.

It is worth noting that, of course, productivity is the most important, from the point of view of theory, the determinant of the decision to enter the foreign market, its impact on the intensity of exports still unclear on the basis of the literature. The results of empirical research presented by researchers are also not unambiguous. Egger and Kesina (2014) obtained a negative impact of productivity on the intensive export factor. Similar results were presented by Bellone et. al. (2010). Research by Minetti and Zhu (2010) indicate a completely different relationship, and the results are significant regardless of the corrections that authors introduce to their models. The obtained results in the case of Poland support Chaney's model, a positive impact of productivity on the intensity of exports was obtained. Since enterprises cover production costs for export from profits generated on the domestic market, companies with higher productivity should achieve higher profits in the country, and as a result, have no problems with financing variable costs related to current production for export. It is worth noting that the export activity of enterprises should be stimulated by influencing the increase of productivity and innovativeness of companies. Financial constraints may also have an indirect impact on export activity, if, for example, they cause a drop in innovation.

The key variable that should be included in the context of researching export determinants is the size of the enterprise. The size of the company turned out to be important. This was considered as a manifestation of the occurrence of information asymmetry, because smaller companies are generally also younger, so financial institutions have problems with collecting data concerning them, and therefore the costs of credit for such enterprises are larger.

The obtained results emphasize the potential role of institutions in influencing credit restrictions, exporters' behavior and general well-being. Since credit restrictions are important and connection between the number of served directions of exports and an increase in exports, obtaining additional liquidity due to presence on one market may result in entering another.

\section{Conclusions}

The article presents a methodological framework for the analysis of sectoral risk and an evaluation of the financial condition in sectoral level and assess the contribution of different sectors to the overall level of risk. When measuring the 
sectoral risk, it is worth paying attention to the existing challenges related to corporate risk default measurement as well as measuring sectoral links and the presence of different degree of dependence of the cross-section in the form of economic proximity and relations between sectors of the economy. The hypothesis was verified that the financial constraints of enterprises affect decisions making by prospective exporters (Chaney, 2016) and sales in foreign markets (Manova, 2013). Taking into account the financial constraint in the form of the PD variable illustrates the liquidity constraints faced by industrial enterprises and problems with obtaining external financing sources.

Based on the results of the evaluation of the risk associated with the financial condition of enterprises, it was found that small and medium-sized enterprises faced a higher risk. The large entities usually (in more than 90\%) fell under the safer risk classes. In 2015, the highest percentage of small and medium-sized enterprises with negative value of net goodwill was observed in the service sector (the accommodation and food service activities sector $(15 \%)$, the information and communication sector $(13 \%)$, the retail sector $(11 \%)$ and the business service sector $(11 \%)$ ); in the case of large enterprises, it was observed in the information and communication sector $(12 \%)$ and in the mining sector (11\%). The lowest risk of bankruptcy was observed in the pharmaceutical industry (especially in the case of large enterprises) and the highest risk of bankruptcy - in the mining sector (where the PD was equal to or higher than 1\%). Sectoral risk affects the size of the economic capital of banks. This risk materializes when the situation deteriorates in one of the sectors of the economy, for which the bank has adopted excessively high exposure.

Based on the literature review two stylised facts emerge: exporters perform substantially better than their non-exporting competitors; there are wide crosscountry differences in enterprise export behaviour. Exporters were characterised by better financial equipment. Using a large panel data of Polish firms, there was evidence that financial constrains (PD - Probability of Default) matter for export participation and sales in foreign markets $(-0,177$ and $-0,184$ respectively). This result corroborates the idea that the relevance of financial constraints was due to the presence of sunk entry costs. Enterprises need to borrow to cover part of the variable costs related to production for export. Similar results were obtained by Minetti and Zhu (2010) for Italian companies' and by Kiendrebeogo and Minea (2013) for Egyptian firms. Financial constraints are also a trade barrier that causes a slowdown in the growth and development of the private sector, especially in developing countries with a poorly developed financial market. Moreover, financial constraints may lead to a drop in the volume of international trade, which is the driving force of particularly emerging economies.

The results of the article are important for political decisions. They can be a lesson that will help you understand the consequences of the last crisis. The credit crunch may end up selecting firms on the basis of their deep pockets, rather than their 
productivity, with negative effects on the overall competitiveness of the economic system. Due to the results of the study, estimating the effects of credit restrictions can be very important for designing appropriate policy interventions.

\section{References}

Accornero, M. et al. (2017) "Credit risk in banks' exposures to non-financial firms", European Financial Management, Vol. 1, No. 17, pp. 1-17, doi: 10.1111eufm. 12138.

Arellano, M., Bond, S. (1991) "Some Tests of Specification for Panel Data", Review of Economic Studies, Vol. 58, No. 2, pp. 277-297, doi: 10.2307/2297968.

Bellone, F., et al. (2010) "Financial constraints and firm export behavior", The World Economy, Vol. 33, No. 3 pp. 347-373, doi: 10.1111/j.1467-9701.2010. 01259.x.

Blocher, E., Chen, K. B. (1978) "Assessing Industry Risk by Ratio Analysis A Comment", The Accounting Review, Vol. 53, No. 1, pp. 204-209.

Blundell, R. W., Bond, S. R. (1998) "Initial Conditions and Moment Restrictions in Dynamic Panel Data Models", Journal of Econometrics, Vol. 87, No. 1, pp. 115-143, doi: 10.1016/s0304-4076(98)00009-8.

Cespedes, G. et al. (2005) "A simple Multi - Factor. "Factor Adjustment" for the Treatment of Diversification in Credit Capital Rules", Journal of Credit Risk, Vol. 2, No. 3, pp. 57-85, doi: 10.21314/JCR.2006.039.

Chaney, T. (2016), "Liquidity constrained exporters", Journal of Economic Dynamics and Control, Vol. 72, No. 1, pp. 141-154, doi: 10.1016/j.jedc.2016.03.010.

Das, S. R., et al. (2007) "Common Failings: How Corporate Defaults Are Correlated", The Journal of Finance, Vol. 62, No. 1 pp. 93-117, doi: 10.1111/j. 1540-6261.2007.01202.x.

Demsetz, H. (1973) "Industry structure, market rivalry, and public policy", The Journal of Law and Economics, Vol. 16, No. 1, pp. 1-9, doi: 10.1086/466752.

De Servigny, A., Renault, O. (2002) "Default correlation: empirical evidence", Standard \& Poor's, Working Paper, Available at $<$ https://www.researchgate.net/ publication/228679968_Default_correlation_Empirical_evidence>, [Accessed: June 06, 2018].

Düllmann, K., Masschelein, N. (2006) "Sector Concentration in Loan Portfolios and Economic Capital", National Bank of Belgium, Working Paper, No. 105, Available at <https://www.researchgate.net/publication/228679968_Default_ correlation_Empirical_evidence>, [Accessed: June 06, 2018].

Egger, P. H., Kesina, M. (2014) "Financial Constraints and the Extensive and Intensive Margin of Firm Exports Panel Data Evidence from China", Review of Development Economics, Vol. 18, No. 4, pp. 625-639, doi: 10.1111/rode.12107. 
Esposito, F. (1985) "Industry risk and market structure", Review of Industrial Organization, Vol. 2, No. 4, pp. 306-320, doi: 10.1007/bf02418919.

ESRB (2015) "A review of macro-prudential policy in the EU one year after the introduction of the CRD $\backslash$ CRR,European Systemic Risk Board", European Systemic Risk Board, Available at <https://www.esrb.europa.eu/pub/pdf/ other/150625_review_macroprudential_policy_one_year_after_intro_crdcrr.en. pdf>, [Accessed: June 06, 2018].

Falk, H., Heintz, J.A. (1975) "Assessing Industry Risk by Ratio Analysis", The accounting Review, Vol. 50, No. 4, pp. 758-779.

Gregoriou, G., Hoppe, Ch., When, C. (2010) "The Risk Modeling Evaluation Handbook Rethinking Financial Risk Management Methodologies in the Global Capital Markets", McGraw Hill Education, New York.

Heitfield, E., Burton, S., Chomsisengphet, S. (2006) "Systematic and idiosyncratic risk in syndicated loan portfolios", Journal of Credit Risk, Vol. 2, No. 3, pp. 3-31, doi: 10.21314/jcr.2006.038.

Jankowitsch, R., Pichler, S., Schwaiger, W. (2007) "Modelling the economic value of credit rating systems", Journal of Banking \& Finance, Vol. 31, Vol. 1, pp. 181-198, doi: 10.1016/j.jbankfin.2006.01.003.

Iosifidi, M., Kokas, S. (2015) "Who lends to riskier and lower - profitability firms? Evidence from the syndicated loan market", Journal of Banking \& Finance, Vol. 61, No. 1, pp. S14-S21, doi: 10.1016/j.jbankfin.2015.02.008.

Kiendrebeogo Y., Minea A., (2016) "Financial Factors and Manufacturing Exports: Theory and Firm-level Evidence From Egypt", The Journal of Development Studies, Vol. 53, No. 12, pp. 2197-2213, doi: 10.1080/00220388.2016.1251583.

Manova K. (2013), "Credit constraints, heterogeneous firms, and international trade", The Review of Economic Studies, Vol. 80, No. 2, pp. 711-744, doi: $10.1093 / \mathrm{restud} / \mathrm{rds} 036$.

Minetti R., Chun Zhu S., (2011) "Credit constraints and firm export Microeconomic evidence from Italy", Journal of International Economics, Vol. 83, No. 2, pp. 109-125, doi: 10.1016/j.jinteco.2010.12.004.

Merton, R. C. (1974) "On the Pricing of Corporate Debt The Risk Structure of Interest Rates", Journal of Finance, Vol. 29, No. 2, pp. 449-470, doi: 10.1111/ j.1540-6261.1974.tb03058.x.

Nguyen, P. (2007) "nonbinROC: Software for Evaluating Diagnostic Accuracies with Non-Binary Gold Standards", Journal of Statistical Software, Vol. 21, No. 10, doi: 10.18637/jss.v021.i10.

Nehrebecka, N. (2016) "Approach to the assessment of credit risk for non-financial corporations. Evidence from Poland", IFC Bulletins chapters, in: Bank for International Settlements (ed.), Combining micro and macro data for financial stability analysis, Vol. 41, Bank for International Settlements. 
Nehrebecka, N., Dzik, A., (2016) "Construction measures of bankruptcy: Case study of Polish enterprises", Global Business and Economics Review, Vol. 18, No. 3/4, pp. 420-444, doi: 10.1504/gber.2016.076234.

Nehrebecka, N., A. Dzik-Walczak, (2018) "The dynamic model of partial adjustment of the capital structure. Meta-analysis and a case of Polish enterprises", Zbornik Radova Ekonomskog Fakulteta u Rijeci-Proceedings of Rijeka Faculty of Economics, Vol. 36, No. 1, pp. 55-81, doi: 10.18045/zbefri. 2018.1.55.

Saldias, M. (2013) "A Market-based Approach to Sector Risk Determinants and Transmission in the Euro Area", Journal of Banking \& Finance, Vol. 37, No. 11, pp. 4534-4555, doi: 10.1016/j.jbankfin.2013.01.026.

\title{
Procjena sektorskog rizika s posebnim naglaskom na izvozna poduzeća u Poljskoj
}

\author{
Natalia Nehrebecka ${ }^{1}$
}

\begin{abstract}
Sažetak
U članku je prikazan metodološki okvir za analizu sektorskog rizika i procjenu financijskog stanja na razini sektora. Osim toga, potvrđena je hipoteza da financijska ograničenja poduzeća utječu na odluke potencijalnih izvoznika $i$ prodaje na stranim tržištima. Empirijska analiza temeljena je na pojedinim podacima iz različitih izvora (od 2005. do 2016.godine) uključujući platna bilancu $i$ račun dobiti $i$ gubitka (Statistički ured), financijske podatke $i$ podatke o ponašanju. Procjena se sastoji od dva dijela. Prvi dio prikazuje financijsku snagu koja ovisi o neto vrijednosti poduzéca. Financijska snaga definira financijsku sposobnost poduzeća. Drugi dio prikazuje model vjerojatnosti (PD). Statistički model temelji se na logističkom regresijskom modelu i daje procjenu godišnjeg $P D-a$ procijenjene tvrtke. Na temelju rezultata procjene rizika povezanih $s$ financijskim stanjem poduzeća, utvrđeno je da su mala i srednja poduzeća suočena s višim rizikom. Najniži rizik od stečaja bio je u farmaceutskoj industriji a najveći rizik u rudarskom sektoru. Karakteristika izvoznih poduzeća jest bolja financijska opremljenost.
\end{abstract}

Ključne riječi: sektorski rizik, stečajni rizik, metode ocjenjivanja, izvoz

JEL klasifikacija: C190, G210, L11, L25, G33, M13

\footnotetext{
1 Docent, Warsaw University - Faculty of Economic Sciences, Dhuga 44/50, 00-241 Varšava, Poljska. National Bank of Poland, Świętokrzyska 11/21, 00-919 Warszawa. Znanstveni interes: ekonometrijske metode $i$ modeli, statistika i ekonometrija u poslovanju, modeliranje rizika $i$ korporativne financije. Tel.: +48225549 111. Fax: 2283128 46. E-mail: nnehrebecka@wne. uw.edu.pl. Web stranica: http://www.wne.uw.edu.pl/index.php/pl/profile/view/144/.
} 
Natalia Nehrebecka $\bullet$ Sectoral risk assessment with particular emphasis on export...

\section{Apendices}

岕

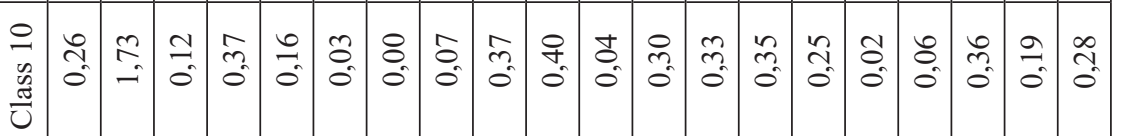

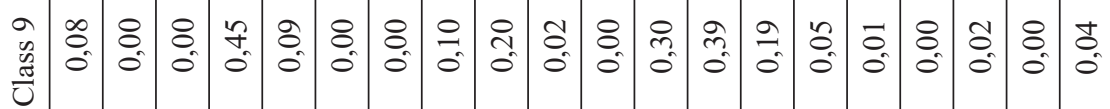

능

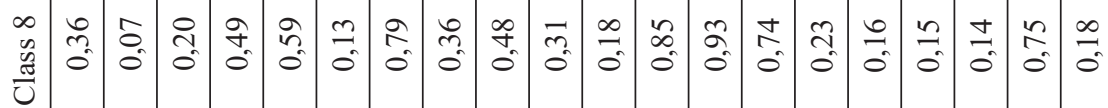

$\Xi$

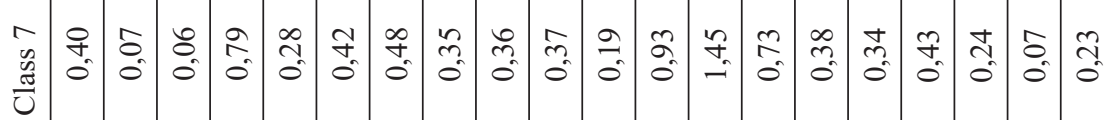

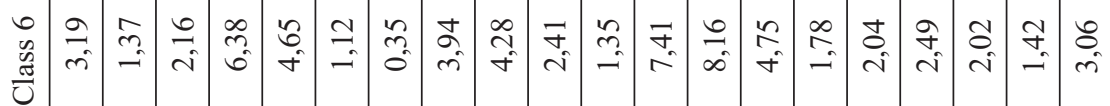

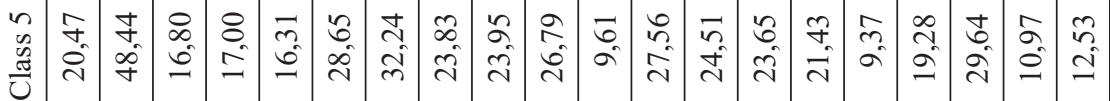

$\underline{1}$

范

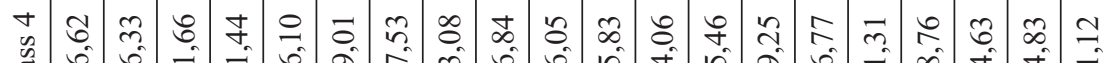

च

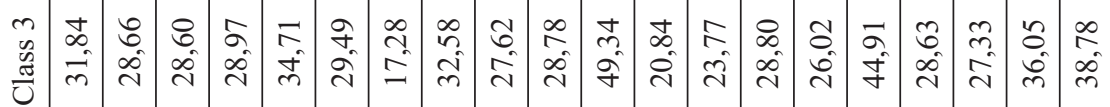

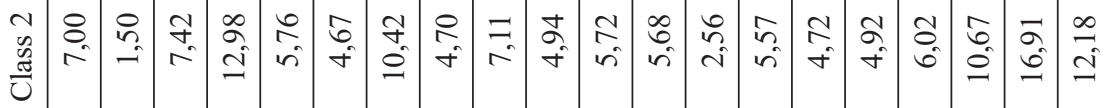

$\stackrel{2}{\rightleftarrows}$

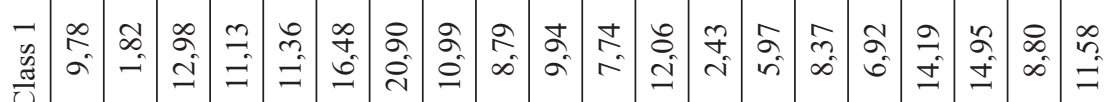

음

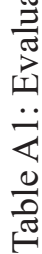

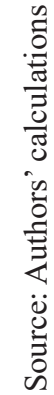


Figure A1: Evaluation of the risk in 2015 (\% of the total number of employees)

in the first two classes in which the PD does not in the last three classes in which the PD is equal to exceed $0,01 \%$ or higher than $1 \%$
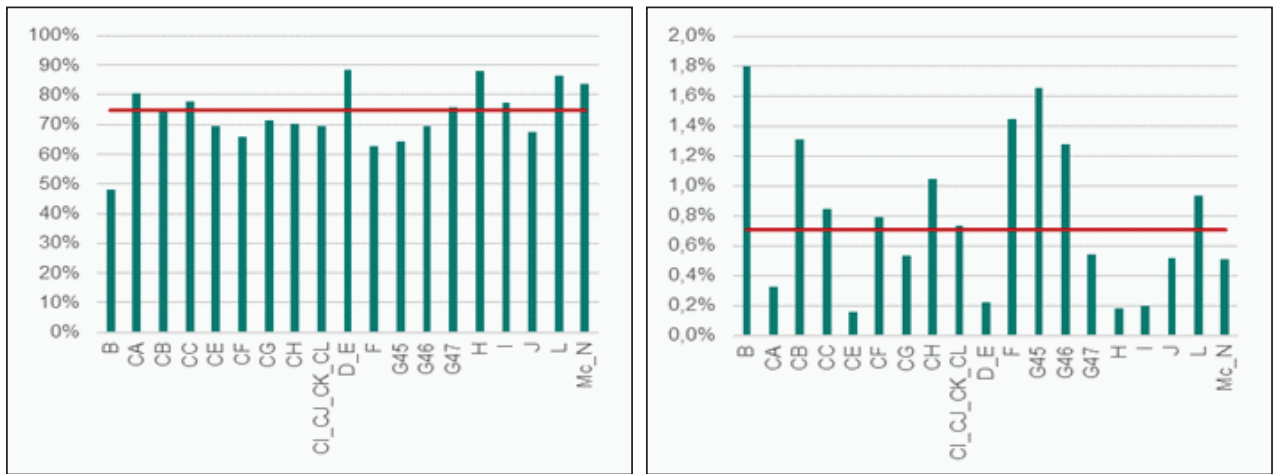

Source: Authors' calculations 
Natalia Nehrebecka $\bullet$ Sectoral risk assessment with particular emphasis on export...

Table A2: Evaluation of companies based on Model

\begin{tabular}{|c|c|c|}
\hline Variables & Value & Partial grade \\
\hline \multicolumn{3}{|l|}{ Quantitative - financial factors } \\
\hline \multirow{4}{*}{$\begin{array}{l}\text { Coverage Ratios - Interest Expense / Net Sales } \\
\text { (average of } 2 \text { years) }\end{array}$} & - INF $-0,00021$ & 155 \\
\hline & $0,00021-0,00143$ & 100 \\
\hline & $0,00143-0,01173$ & 48 \\
\hline & $0,01173-+\mathrm{INF}$ & 0 \\
\hline \multirow{4}{*}{ The return on assets - Net Income / Average Total Assets } & $-\mathrm{INF}--0,02429$ & 0 \\
\hline & $-0,02429-0,01377$ & 25 \\
\hline & $0,01377-0,08877$ & 46 \\
\hline & $0,08877-+\mathrm{INF}$ & 74 \\
\hline \multirow{3}{*}{$\begin{array}{l}\text { Size - logarithm of Total Assets } \\
\text { (median of } 2 \text { years) }\end{array}$} & -INF - 8,12162 & 83 \\
\hline & $8,12162-9,24744$ & 47 \\
\hline & $9,24744-+\mathrm{INF}$ & 0 \\
\hline \multirow{4}{*}{ Net - Asset Structure } & $-\mathrm{INF}--1,07208$ & 0 \\
\hline & $-1,07208--0,39644$ & 82 \\
\hline & $-0,39644-0,69915$ & 146 \\
\hline & $0,69915-+\mathrm{INF}$ & 225 \\
\hline \multirow{4}{*}{$\begin{array}{l}\text { Level of debt - Current Liabilities to Total Assets } \\
\text { (max of } 2 \text { years) }\end{array}$} & $-\mathrm{INF}-0,57879$ & 94 \\
\hline & $0,57879-0,88851$ & 45 \\
\hline & $0,88851-1,18627$ & 23 \\
\hline & $1,18627-+\mathrm{INF}$ & 0 \\
\hline \multirow{3}{*}{$\begin{array}{l}\text { Profit/loss on sales to equity } \\
\text { (median of } 2 \text { years) }\end{array}$} & - INF $--0,17851$ & 0 \\
\hline & $-0,17851-0,35056$ & 82 \\
\hline & $0,35056-+\mathrm{INF}$ & 146 \\
\hline \multicolumn{3}{|l|}{ Qualitative - behavioral factors } \\
\hline \multirow{5}{*}{ Industry sektors } & Industry & 97 \\
\hline & Construction & 0 \\
\hline & Trade & 122 \\
\hline & Transport & 206 \\
\hline & Other services & 225 \\
\hline \multirow{3}{*}{ Payment morality } & To 15 days delay & 200 \\
\hline & To 25 days delay & 150 \\
\hline & Up to 60 days delay & 0 \\
\hline \multirow{3}{*}{ Direction of sales } & Non exporting & 0 \\
\hline & Exporting & 19 \\
\hline & Specialized exporter & 93 \\
\hline \multirow{2}{*}{ Change management } & Yes & 0 \\
\hline & No & 80 \\
\hline
\end{tabular}


Natalia Nehrebecka $\bullet$ Sectoral risk assessment with particular emphasis on export... Zb. rad. Ekon. fak. Rij. • 2018 • vol. $36 \cdot$ no. $2 \cdot 677-700$

\begin{tabular}{|c|c|c|}
\hline Variables & Value & Partial grade \\
\hline \multicolumn{3}{|l|}{ Quantitative - financial factors } \\
\hline \multirow{2}{*}{ Information about purchased cars } & Yes & 90 \\
\hline & No & 0 \\
\hline \multirow{2}{*}{ Information about purchased real estate } & Yes & 100 \\
\hline & No & 0 \\
\hline \multicolumn{3}{|l|}{ Sector riskiness } \\
\hline \multirow{3}{*}{$\begin{array}{l}\text { Gross profit margin - Gross Profit / Net revenues } \\
\text { (maximum of } 2 \text { years) }\end{array}$} & $-\mathrm{INF}-0$ & 58 \\
\hline & $0-0,28417$ & 25 \\
\hline & $0,28417-+\mathrm{INF}$ & 0 \\
\hline \multirow{4}{*}{$\begin{array}{l}\text { Liquidity - Securities for trading in cash / (Short-term } \\
\text { liabilities and special funds + Accruals) } \\
\text { (minimum of } 2 \text { years) }\end{array}$} & -INF - 0,02379 & 0 \\
\hline & $0,02379-0,0833$ & 30 \\
\hline & $0,0833-0,56876$ & 69 \\
\hline & $0,56876-+\mathrm{INF}$ & 135 \\
\hline \multirow{4}{*}{$\begin{array}{l}\text { Debt Ratio - Long-temr liabilities / Total Assets } \\
\text { (average of } 2 \text { years) }\end{array}$} & -INF - 0,12404 & 157 \\
\hline & $0,12404-0,18827$ & 87 \\
\hline & $0,18827-0,3108$ & 40 \\
\hline & $0,3108+\mathrm{INF}$ & 0 \\
\hline
\end{tabular}

Source: Authors' calculations 